\title{
Antioxidant responses against aluminum metal stress in Geitlerinema amphibium
}

\author{
Biswajita Pradhan ${ }^{1}$. Srimanta Patra ${ }^{1}$. Soumya Ranjan Dash ${ }^{1}$. Sairendri Maharana ${ }^{1} \cdot$ Chhandashree Behera $^{1}$. \\ Mrutyunjay Jena ${ }^{1}$ (i)
}

Received: 4 February 2020 / Accepted: 25 March 2020 / Published online: 2 April 2020

(c) Springer Nature Switzerland AG 2020

\begin{abstract}
In the current scenario, aluminum is one of the major metals that cause environmental pollution and has ill impact on organism health. As around $40 \%$ of bauxite deposits of India are available in Odisha, aluminum toxicity in the soil has impacted as an intimidating problem of Odisha. This aluminum metal pollution is regarded as a primary factor for limiting crop productivity in acidic soils of tropic and subtropic countries. The presence of a high degree of aluminum metal in the soil leads to loss of beneficial microflora, i.e., nitrogen-fixing cyanobacteria that play a key role in soil fertility. Hence, this investigation was performed on a filamentous non-heterocystous cyanobacterium Geitlerinema amphibium isolated from the aluminum-polluted sites, i.e., NALCO, Ash pond, Angul to uncover the defense mechanism of the strain exhibited under such stress. The strain was treated with different doses of $\mathrm{AlCl}_{3}(0-100 \mu \mathrm{M})$, and we observed redox imbalance leading to oxidative stress. Post-treatment of $\mathrm{AlCl}_{3}$, a remarkable decline in growth was evident with possible modifications in pigments associated with the phenomena. Further to combat against the stress under the redox environment, the organism activated antioxidant enzymes CAT, APX, GR, GPX, and SOD which were measured to identify the key responses involved in it. All the stress responsive enzymes were analyzed to demonstrate the interlink between the induction of stress and their detoxification through cellular response. The outcome of the work explored the multifaceted role of oxidative upset caused by $\mathrm{AlCl}_{3}$ pollutants and the cellular antioxidative strategies deployed by G. amphibium to nullify them.
\end{abstract}

Keywords Cyanobacteria $\cdot$ Aluminum $\cdot$ Antioxidants $\cdot$ Stress $\cdot$ Reactive oxygen species (ROS)

\section{Introduction}

Aluminum (Al) is one of the abundant metal pollutants found in the earth's crust. The major sources of Al pollutants are industrial mining, bauxite ore smelting, aluminum-made house appliances, food additives, wrapping materials, cosmetics and medicines waste [38]. As a result of the high demand for aluminum, the aluminum industries are steadily growing worldwide. In Odisha, Al pollution has been a looming problem since the large quantity of bauxite ore mines is being smelted and refined at
VENDANTA mines and NALCO, respectively. The surroundings of these sites are contaminated by Al pollutants, and a sharp decline in crop production and human health has been observed in recent years. The contamination of $\mathrm{Al}$ pollutants heavily affects the terrestrial and aquatic ecosystem and drives a major concern toward their treatment. Cyanobacteria are autotrophic microorganisms regarded as the most prominent component of the aquatic and soil microbiota. These groups of bacteria contribute a major amount of fixed form of nitrogen to the soil and also act as primary producers of all aquatic ecosystems.

Mrutyunjay Jena, mrutyunjay.jena@gmail.com | ${ }^{1}$ Algal Biotechnology and Molecular Systematic Laboratory, Post Graduate Department of Botany, Berhampur University, Bhanja Bihar, Berhampur 760007, India. 
Cyanobacteria are also widely regarded as the bio-indicators of pollution, and diversity of these organisms is commonly subjected to stress due to metal pollutants in the environment [7]. Further, cyanobacteria exhibit very specific and distinctive protective to manage the toxicity of metal stress and survive during such harsh environment [13]. Several studies have been carried out on the toxicity of different heavy metals stress $(\mathrm{Cu}, \mathrm{Zn}$, and $\mathrm{Cd})$ on different microalgae and cyanobacteria [22, 31, 32, 34, 35]. In response to heavy metal stress, the cells undergo an oxidative burst, consequently producing huge amounts of reactive oxygen Species (ROS) [32]. In general, the reduced metal ions react with $\mathrm{H}_{2} \mathrm{O}_{2}$ and produce hydroxyl radicals (HO) that damage different biomolecules [9]. Moreover, the noticeable phytotoxic symptoms exhibited by Al metal ions include defects in photosynthesis by change in the function of the associated pigment system and affect the cellular cytoplasmic-nuclear compartments to render the normal metabolism $[1,29]$. However, the adaptability of cyanobacteria against the Al metal toxicity and antioxidant modulation in response to Al-induced oxidative stress mechanisms are yet to be addressed. Keeping the problems in mind, the present work was hypothesized to identify the key responses shown by cyanobacteria in Alpolluted sites of Odisha. Hence, a valiant attempt has been made to investigate the possible role of Al-mediated stress on cyanobacterium G. amphibium and the antioxidant defense mechanism enforced to eradicate it. This study will be helpful to monitor regular surveillance and management of necessary impact assessment for environmental pollution caused by aluminum.

\section{Materials and methods}

\subsection{Isolation and purification of cyanobacterial strain}

The soil and water samples were collected from aluminumpolluted sites the NALCO industry, Angul, Odisha (Ash pond, latitude and longitude $20^{\circ} 50^{\prime} 57.36^{\prime} \mathrm{N}$, and $85^{\circ} 9^{\prime}$ $\left.14.97^{\prime} \mathrm{E}\right)$. A non-heterocystous filamentous cyanobacterium strain was isolated by the serial dilution method. The organism was purified by repeated strike plate method and periodical microscopic observation. Finally, the pure strain has been identified as G. amphibium and the pure strain has submitted to Berhampur University algal culture collection by assigning strain no., i.e., G. amphibium BUACC21. The purified strain has been transferred to the flask containing the BG-11 nutrient medium with $\mathrm{NaNO}_{3}$ and allowed to grow for 21 days.

\subsection{Culture condition and aluminum treatment}

The culture was treated with a different molar concentration of aluminum chloride $\left(\mathrm{AlCl}_{3}\right)$ (Merck, QK3Q632337) such as control, $1 \mu \mathrm{M}, 10 \mu \mathrm{M}, 50 \mu \mathrm{M}$, and $100 \mu \mathrm{M}$. The $\mathrm{pH}$ of all treated groups along with control was adjusted to 4.5. All the cultures were grown at $23 \pm 2{ }^{\circ} \mathrm{C}$ and under $7.5 \mathrm{~W} \mathrm{~m}^{2}$ light intensity in the culture room. The samples were harvested on the 21st day of the exponential phase for growth and further analysis.

\subsection{Growth measurement}

Post-21st day, the effect of $\mathrm{AlCl}_{3}$ on the growth of $G$. amphibium under different micromolar $(\mu \mathrm{M})$ concentration was measured spectrophotometrically (Eppendorf, Kinetic Bio-Spectrometer 6136GK603582) [25].

\subsection{Pigments and protein analysis}

\subsubsection{Pigments analysis}

The chlorophyll content of G. amphibium was estimated by hot extraction methods. Cyanobacterial culture (Control, 1-100 $\mu \mathrm{M}, 10 \mathrm{ml}$ ) was centrifuged ( $8000 \mathrm{rpm}, 5 \mathrm{~min}$, $4{ }^{\circ} \mathrm{C}$ ) for chlorophyll-a estimation. Post-centrifugation, $90 \%$ methanol $(10 \mathrm{ml})$ was added to the resultant pellet. After repeated vortex, the mixture was placed on the water bath for $30 \mathrm{~min}$ at $60^{\circ} \mathrm{C}$. Further, the samples were centrifuged (8000 rpm, $5 \mathrm{~min}, 4^{\circ} \mathrm{C}$ ) and the absorbance of the supernatant was measured by UV-Vis spectrophotometer at 665 and $650 \mathrm{~nm}$, respectively, taking methanol as blank. The content of chlorophyll-a was calculated using the equation described by [37]. Phycobiliproteins such as phycocyanin $(\mathrm{PC})$, phycoerythrin (PE) and allophycocyanin (APC) content were measured spectrophotometrically [18].

\subsubsection{Protein extraction and estimation of antioxidant enzymes}

Protein content was measured spectrophotometrically. Post-centrifugation $(8000 \mathrm{rpm}, 10 \mathrm{ml})$, the precipitated algal suspensions were homogenized using $5-\mathrm{mm}$ stainless steel beads (Qiagen, 69989) for $10 \mathrm{~min}$ at $40 \mathrm{~m} \mathrm{~s}^{-1}$ in a Tissue Lyser (Model No LT No-23.1001/07581, Qiagen) in phosphate buffer ( $2 \mathrm{ml}$ of $50 \mathrm{mM}, \mathrm{pH} 7.0)$, containing EDTA $(0.1 \mathrm{mM})$, and polyvinyl-polypyrrolidone $(1 \%(\mathrm{w} / \mathrm{v}))$ and protease inhibitor at $4{ }^{\circ} \mathrm{C}$. For ascorbate peroxidase assay, the grinding buffer additionally contained $5 \mathrm{mM}$ of ascorbate (Himedia, Mumbai, CMS040-100G). The homogenates were centrifuged at $12,000 \mathrm{rpm}$ for $15 \mathrm{~min}$ at $4{ }^{\circ} \mathrm{C}$, and supernatant was stored at $-20^{\circ} \mathrm{C}$ for the determination of 
protein and enzyme activities. The soluble protein content was determined according to [8], and bovine serum albumin (Himedia. Cat No. GRM105-5G) was used for calibration of the standard curve. Further, different antioxidant enzymes, namely catalase (CAT), superoxide dismutase (SOD), guaiacol peroxidase (GPX), ascorbate peroxidase (APX) and glutathione reductase (GR), were estimated by a UV-Vis spectrophotometer.

Catalase (CAT) activity of the above strain was estimated according to the method of [12]. Catalase activity was analyzed by spectrophotometrically by adding the enzyme extracts into the $3 \mathrm{~mL}$ of the reaction mixture. The $3 \mathrm{~mL}$ of reaction mixture contains $50 \mathrm{mM}$ of sodium phosphate buffer of (pH 7) $10 \mathrm{mM}$ of $\mathrm{H}_{2} \mathrm{O}_{2}$ (Merck, CC3C630119) and $50 \mu \mathrm{l}$ of the enzyme extracts. Catalase activity was determined by measuring the decreasing absorbance at $240 \mathrm{~nm}$ as a result of the degradation of $\mathrm{H}_{2} \mathrm{O}_{2}$. Enzyme activity was calculated using the extinction coefficient $\left(0.036 \mathrm{mM}^{-1} \mathrm{~cm}^{-1}\right)$. The CAT activity was expressed in $\mathrm{nmol}$ of $\mathrm{H}_{2} \mathrm{O}_{2}$ utilized $\mathrm{mg}^{-1}$ protein $\mathrm{min}^{-1}$.

Ascorbate peroxidase (APX) activity of the above strain was estimated [20]. APX activity was measured spectrophotometrically by adding the enzyme extracts into the $3 \mathrm{~mL}$ of the reaction mixture. The $3 \mathrm{~mL}$ of reaction mixture contained $50 \mathrm{mM}$ of sodium phosphate buffer of $(\mathrm{pH} 7)$, $0.5 \mathrm{mM}$ of Ascorbate (Himedia, CMS040) in $10 \mathrm{mM}$ of $\mathrm{H}_{2} \mathrm{O}_{2}$ (Merck, CC3C630119) and $50 \mu \mathrm{l}$ of the enzyme extract. APX activity was determined by measuring the decreasing absorbance at $290 \mathrm{~nm}$ as a result of the degradation of $\mathrm{H}_{2} \mathrm{O}_{2}$. Enzyme activity was calculated using the extinction coefficient $\left(2.8 \mathrm{mM}^{-1} \mathrm{~cm}^{-1}\right)$. The APX enzyme activity was expressed in $\mu \mathrm{mol}$ of ascorbate oxidized $\mathrm{mg}^{-1}$ protein $\min ^{-1}$.

Guaiacol peroxidase (GPX) activity was determined [1] in the enzyme extract by measuring the increase in the absorbance at $470 \mathrm{~nm}$ due to formation of tetraguaiacol $\left(\varepsilon=26.6 \mathrm{mM}^{-1} \mathrm{~cm}^{-1}\right)$ in the reaction mixture containing $50 \mathrm{mM}$ of sodium phosphate buffer ( $\mathrm{pH} \mathrm{7.0),} 8 \mathrm{mM} \mathrm{H}_{2} \mathrm{O}_{2}$ (Merck, CC3C630119), and 8 mM Guaiacol (Himedia, RM1118), and the activity was expressed as $\mu$ mol of tetraguaiacol formed $\mathrm{mg}^{-1}$ protein $\mathrm{min}^{-1}$.

For the determination of glutathione reductase (GR) activity, an aliquot of the extract containing $50 \mu \mathrm{g}$ protein was added to a $3 \mathrm{ml}$ of reaction mixture containing $0.2 \mathrm{M}$ of Tris-buffer (pH 7.8), 2 mM of EDTA (Himedia, PCT1002), $0.5 \mathrm{mM}$ of GSSG (oxidized glutathione) (Himedia, RM550), and $0.2 \mathrm{mM}$ of nicotinamide adenine dinucleotide phosphate hydrogen (NADPH, Himedia, RM576). The reaction was initiated by the addition of NADPH at $25^{\circ} \mathrm{C}$. GR activity was followed by the decrease in absorbance spectrophotometrically at $340 \mathrm{~nm}$ due to NADPH oxidation $\left(\varepsilon=6.2 \mathrm{mM}^{-1} \mathrm{~cm}^{-1}\right)$ according to [26] and expressed as $\mu$ mol of NADPH oxidized $\mathrm{mg}^{-1}$ protein $\mathrm{min}^{-1}$.
Superoxide dismutase (SOD) activity was determined [20] by measuring inhibition of the photochemical reduction of NBT by the enzyme in the reaction mixture containing $50 \mathrm{mM}$ of sodium phosphate buffer ( $\mathrm{pH} 7.8), 0.1 \mathrm{mM}$ of EDTA (Himedia, PCT1002), $75 \mu$ M of NBT (Himedia, RM578), $13 \mathrm{mM}$ of methionine (Himedia, RM056), 0.3\% (v/v) of Triton X-100 (Himedia, MB031), and $2 \mu \mathrm{M}$ of riboflavin (Himedia, PCT0214). The reaction was initiated at room temperature by switching on the light (Phillips $40 \mathrm{~W} \times 2$ fluorescent tubes) for 8 min and stopped by switching off the light. The absorbance of formazan formed was recorded at $560 \mathrm{~nm}$. One unit of SOD activity was defined as the amount of the enzyme that inhibited NBT reduction by $50 \%$ and expressed as units $\mathrm{mg}^{-1}$ protein $\mathrm{min}^{-1}$.

\subsection{Statistical analysis}

All the experiments were done by taking the sample in triplicate, and pooled data were subjected to one-way analysis of variance (ANOVA) which is followed by the least significance difference (LSD). The ${ }^{* *} p$ value $\leq 0.01$ was found to be statistically significant.

\section{Results}

\subsection{Aluminum-induced stress affects the growth rate by affecting the photosynthetic pigments in G. amphibium}

In response to different concentrations $(0-100 \mu \mathrm{M})$ of $\mathrm{AlCl}_{3}$, the growth rate of $\mathrm{G}$. amphibium was decreased significantly. With an increase in the dose of $\mathrm{AlCl}_{3}$, a substantial decline in growth was observed. As compared to control, we observed a $56.67 \%$ of retardation at $100 \mu \mathrm{M}$ (Fig. 1a). Reduced content of the chlorophyll-a was evident during the progressive induction of stress. $A(0.009 \mu \mathrm{g} / \mathrm{mL})$ of chlorophyll-a was observed at control which is reduced during treatment of $100 \mu \mathrm{M}(0.002 \mu \mathrm{g} / \mathrm{mL})$ (Fig. 1b). A similar reduction of the three accessory light-harvesting phycobiliproteins was observed with an increase in the concentration of dose. Although a minimal deviation of reduction of PC was observed, a complete decline in APC and PE was evident at the highest dose. The PC content was reduced from control $(0.0045 \mu \mathrm{g} / \mathrm{mL})$ to $100 \mu \mathrm{M}(0.0027 \mu \mathrm{g} / \mathrm{mL})$, respectively (Fig. 1c), whereas APC declined from control $(0.024 \mu \mathrm{g} / \mathrm{mL})$ to $100 \mu \mathrm{M}(0.007 \mu \mathrm{g} / \mathrm{mL})$ (Fig. $1 \mathrm{~d})$ at same interval of dose. The PE too followed the same pattern as reduced $100 \mu \mathrm{M}(0.0038 \mu \mathrm{g} / \mathrm{mL})$ over control $(0.0088 \mu \mathrm{g} /$ $\mathrm{mL}$ ) (Fig. 1e). 
Fig. 1 Effect of aluminum $\left(\mathrm{AlCl}_{3}\right)$ on growth, change in pigment and protein content in G. amphibium. Post-treatment of different doses of $\mathrm{AlCl}_{3}$ in the experimental strain G. amphibium for 21 days, the growth (a) of the strain was evaluated. Further investigation of photosynthesis-associated pigments such as chlorophyll-a (b), phycocyanin (c), allophycocyanin (d), and phycoerythrin (e) was performed. The total soluble protein content was determined to establish a link between stress and antioxidant response against it (f). All the experiments were done by taking the sample in triplicate, and pooled data were subjected to one-way analysis of variance (ANOVA) which is followed by the least significance difference (LSD). The ${ }^{* *} p$ value $\leq 0.01$ was found to be statistically significant
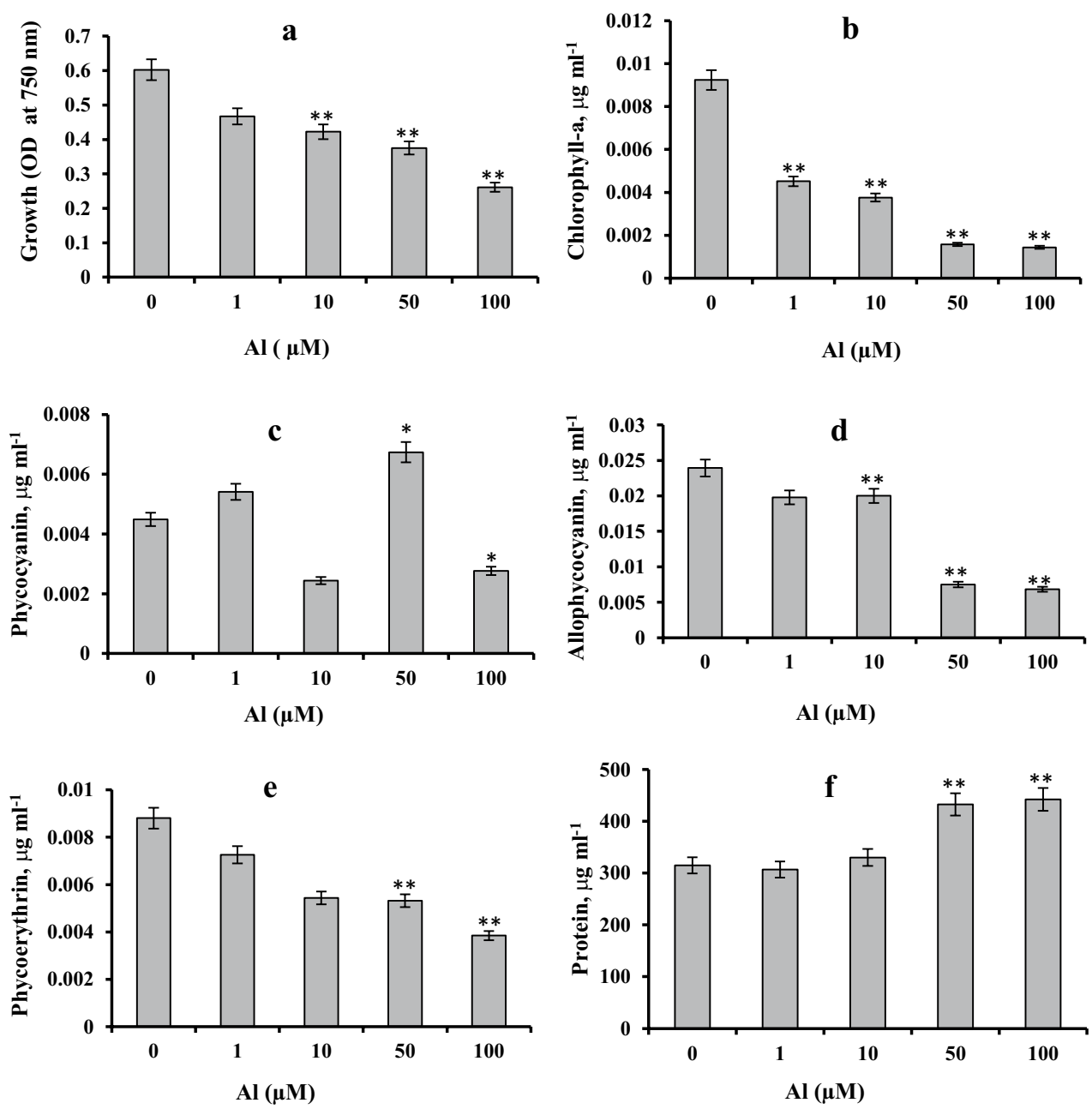

\subsection{G. amphibium promote antioxidant enzymes as a defense mechanism against aluminum-induced stress}

The total soluble protein content of the strain was determined to mark the potential role of aluminum-induced stress as an increase in total soluble protein subsequently enhances the rate of abundance of stress-responsive proteins. A substantial increase in total soluble protein was observed with increasing doses. The results displayed an increase in protein content, i.e., $(100 \mu \mathrm{M}: 442.14 \mu \mathrm{g} /$ $\mathrm{mL})$ at highest as compared to the control $(314.17 \mu \mathrm{g} /$ $\mathrm{mL}$ ) (Fig. 1f). Further determination of the antioxidative enzymes like CAT, APX, GR, GPX and SOD activity was done that combats the aluminum-induced stress. The induction of stress marked an enhanced activity of the above-mentioned enzymes. The activity of CAT (control 74.07:100 $\mu \mathrm{M}$ 259.26) $\mathrm{H}_{2} \mathrm{O}_{2}$ utilized $\mathrm{mg}^{-1}$ protein (Fig. 2a) and APX (control 0.12: $100 \mu \mathrm{M}$ 5.00) ascorbate consumed $\mathrm{mg}^{-1}$ protein $\mathrm{min}^{-1}$ were increased dose-dependently (Fig. 2b). In response to induction of stress the GR (control
1.12: $100 \mu \mathrm{M}$ 3.93) NADPH oxidized $\mathrm{mg}^{-1}$ protein $\mathrm{min}^{-1}$ (Fig. 2c) and GPX (control 0.95: $100 \mu \mathrm{M}$ 4.52) tetraguaiacol formed $\mathrm{mg}^{-1}$ protein $\mathrm{min}^{-1}$ also exhibited the similar pattern (Fig. 2d). Another prominent antioxidative enzyme SOD (control 2.4: $100 \mu \mathrm{M}$ 5.24) inhibition of NBT reduced by $50 \% \mathrm{mg}^{-1}$ protein too followed a noticeable hike with subsequent increase in the dose (Fig. 2e). The hypothesis uncovered the potential role of aluminum to induce oxidative stress on G. amphibium and the antioxidant mechanisms deployed by the strain to combat against such stress.

\section{Discussion}

Bioaccumulation and toxicity of heavy metals by cyanobacteria has often been discussed, as these photosynthetic organisms are regarded as the primary producers in the aquatic ecosystems. The effect of heavy metal toxicity has been explored recently with a limited notation on Al metal toxicity $[2,4,30,36]$. Reported studies have 
Fig. 2 Effect of aluminum $\left(\mathrm{AlCl}_{3}\right.$ ) on antioxidant enzymes as a defense mechanism against ROS generation in $G$. amphibium. After treatment of different doses of $\mathrm{AlCl} 3$, the antioxidant enzyme CAT (a) was analyzed to demonstrate the detoxification of free radicals under oxidative upset. Further quantification of APX

(b), GPX (c) were done to clarify the mechanism of ROS detoxification. The GR (d) and SOD (e) were measured spectrophotometrically to clarify the overall antioxidant response exhibited by the strain to combat against stress. All the experiments were done by taking the sample in triplicate and pooled data were subjected to one-way analysis of variance (ANOVA) which is followed by the least significance difference (LSD). The ${ }^{* *} p$ value $\leq 0.01$ was found to be statistically significant
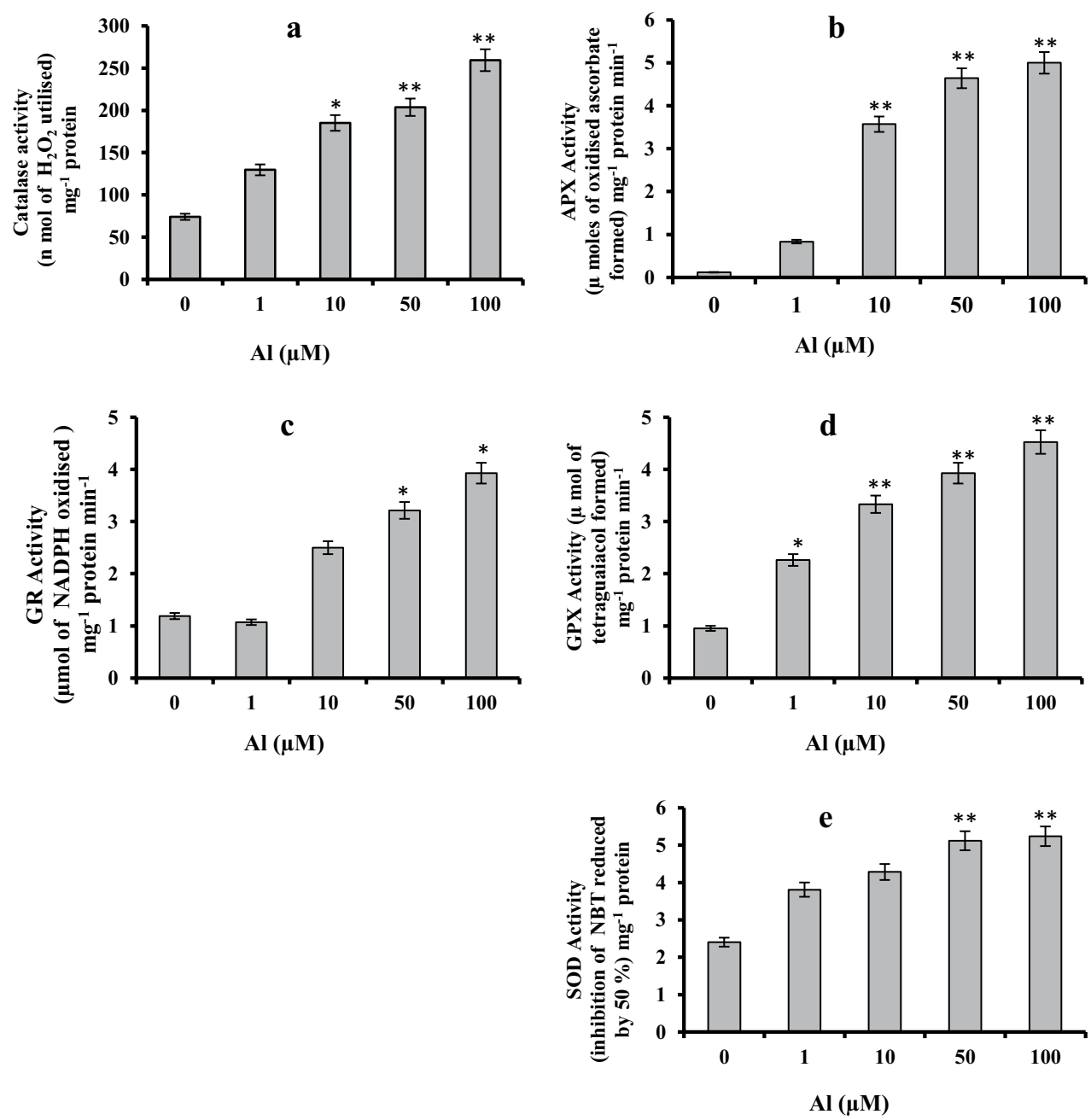

remarked the colossal interlink between metal toxicity and $\mathrm{pH}$ of the soil as metal ions and $\mathrm{H}^{+}$at the cell surface get disturbed in the process $[11,15,28]$. The $\mathrm{pH}$ also regulates the growth and physiological parameters under induced stress environment. To get rid of such toxic phenomena and oxidative upset, the organisms deploy several antioxidative enzymes that perform as the inevitable comrades between stress and tolerance. At pH 4.5, the treatment of Al provoked associated stresses that regulate the physiochemical activities of G. amphibium and elicits an antioxidant defense mechanism.

Prolonged stress induced by $\mathrm{AlCl}_{3}$ affects tolerance and adaptability by modulating biochemical responses; hence, a lower growth rate was evident. In addition to this, the induction of the negative feedback loop on photosynthetic pigments contributes toward the stunted growth rate of the strain. With our initial findings, we observed a dose-dependent decrease in the growth rate of the strain primarily contributed by the subsequent defects in the cell division. With an increase in dose, the inhibition of cell division resulted in stunted growth of the strain. A high dose treatment displayed maximal growth inhibition during prolonged stress induction. The results obtained are in agreement with that mercury, another heavy metal, affects the growth rate of Chlamydomonas reinhardtii [12]. Exposure to heavy metals generally affects the pigment profile of the strains. A sharp decline in the chlorophyll-a content was observed with increasing doses of Al. The maximal dose displayed the most effective reduction in chlorophylla content, hence disturbing the photosynthesis and associated pathways. Our study is well supported by the previous findings as a higher concentration of copper induces structural dysfunction and malfunctioning of several associated pigments [16]. Similarly, the chlorophyll-associated light-harvesting complex, i.e., phycobiliproteins (PC, APC, and $P E)$, was marked an efficient reduction with increasing Al toxicity. The primary defection of photosynthesis associated pigments, it could be concluded the reduction of growth of a particular strain. Moreover, a reduced phycobiliprotein concentration was accountable for the reduction in antioxidant properties exhibited by the strain. As these complexes scavenge peroxyl, hydroxyl, and alkoxyl 
radicals efficiently, the metal binding antioxidant phycocyanins prevent lipid peroxidation, resulting in reduced content of this displayed disrupt in the oxidative state. Mechanistically, the decline in phycobiliproteins under tremendous stress could address an enhanced requirement of metabolic energy for responses associated with adaptive mechanisms [14,27].

Under selective macro-element-rich culture condition, usually there is an increase in the cellular protein content. This acts as a primary defense mechanism to combat stress through enzymatic regulation. This response maintains an equilibrium between stress tolerance and biomass productivity. Such supporting reports have been illustrated in different algae and cyanobacteria in the recent past $[17,23]$. Several reports have been stated that under prolonged stress the strain elevates the expression of more proteins to combat it. Al-mediated stress stimulated expression of more soluble proteins and modified physiochemical metabolic pathways to regulate defense mechanisms [1]. Abiotic stresses disclose insightful impacts on proteomes including alterations in protein relative abundance and cellular localization. Those proteins which are usually related to the defensive mechanism of the organism are elevated with an elevation in total protein content. Stress adaptability reveals constitutively enhanced levels of several stress-related proteins subsequently associated with soluble protein. Hence, the soluble protein and cellular protection enzymes increase under abiotic stress [21,24]. Our study exhibited a similar pattern of hike in the total soluble protein content with an increase in Al-mediated stress.

The mechanisms of cellular protection against biotic as well as biotic stresses are primarily modulated by ROSmediated pathways. Exposure to $\mathrm{Al}$ is expected to elevate the intracellular production of $\operatorname{ROS}[1,2,19,33]$. The organisms display an adaptive response toward oxidative stress by regulating antioxidant enzymes. To nullify the oxidative imbalance caused and to mediate cellular detoxification of ROS, the synthesis of new isozymes occurs $[1,6]$. During the peroxidative cycle, the enzyme peroxidase catalyzes the $\mathrm{H}_{2} \mathrm{O}_{2}$ dehydrogenation process. Further, another mechanism of $\mathrm{H}_{2} \mathrm{O}_{2}$ scavenging is mediated by CAT. Our findings demonstrated that, the Al-mediated abiotic stress exhibited a higher CAT activity at higher doses. Another mechanism deployed by this strain to counteract the $\mathrm{H}_{2} \mathrm{O}_{2}$-mediated oxidative imbalance is carried out by APX that acts as a specific negative charge donor to catalyze the reactions. The GR that functions as dimeric disulfide oxidoreductase and utilizes FAD to NADPH also scavenges hydroxyl radicals, singlet oxygen species and various electrophiles [10]. Our study revealed enhanced expression of GR that possibly acts as a threshold defense mechanism. The cellular degradation of $\mathrm{H}_{2} \mathrm{O}_{2}$ by GPX through the reduction of free hydrogen peroxide and release into water is another mechanism exhibited by this strain. We marked an enhanced GPX expression upon induction of stress which is in the line reported in several higher plant species [2]. Further SOD-mediated catalyses for dismutation reaction detoxify the cellular upset $[3,5]$. Our study is in the path of similar finding reported above. A mutualistic correlation of metabolic phenomena and associated molecules are indispensable comrades to abrogate oxidative stress. Under oxidative upset, this strain triggers antioxidative enzymes to equilibrate the unfavorable cellular states.

\section{Conclusion}

The present study concluded that aluminum-mediated provocations of oxidative stress in G. amphibium influence the growth of the strain by altering both primary and associated photosynthetic pigments. To deal with such unfavorable phototoxic environment, this strain reinforces a variety of antioxidant enzymes that scavenge the free radicals produced and maintain an equilibrated intracellular state. These cellular detoxification responses can be elucidated as cellular defense mechanisms for adaptation to stress. Further, the study revealed the underlying mechanism of the stress response and proposed a predictive bioindicator of $\mathrm{AlCl}_{3}$ pollution.

Acknowledgements The authors thank MoEF \& CC, Govt. of India for providing fund to carry out this piece of research work. The authors also thank Berhampur University for providing necessary facilities.

\section{Compliance with ethical standards}

Conflict of interest The authors declare that they have no conflict of interest.

\section{References}

1. Achary VM, Jena S, Panda KK, Panda BB (2008) Aluminium induced oxidative stress and DNA damage in root cells of Allium cepa L. Ecotoxicol Environ Saf 70:300-310. https://doi. org/10.1016/j.ecoenv.2007.10.022

2. Achary VM, Parinandi NL, Panda BB (2012) Aluminum induces oxidative burst, cell wall NADH peroxidase activity, and DNA damage in root cells of Allium cepa L. Environ Mol Mutagen 53:550-560. https://doi.org/10.1002/em.21719

3. Alscher RG, Erturk N, Heath LS (2002) Role of superoxide dismutases (SODs) in controlling oxidative stress in plants. J Exp Bot 53:1331-1341

4. Arunakumara KKIU, Zhang X (2008) Heavy metal bioaccumulation and toxicity with special reference to microalgae. J Ocean Univ China 7:60-64. https://doi.org/10.1007/s11802-008-0060-y 
5. Awasthi JP, Saha B, Panigrahi J, Yanase E, Koyama H, Panda SK (2019) Redox balance, metabolic fingerprint and physiological characterization in contrasting North East Indian rice for Aluminum stress tolerance. Sci Rep 9:8681. https://doi.org/10.1038/ s41598-019-45158-3

6. Birben E, Sahiner UM, Sackesen C, Erzurum S, Kalayci O (2012) Oxidative stress and antioxidant defense. World Allergy Organ J 5:9-19. https://doi.org/10.1097/WOX.0b013e3182439613

7. Blanco-Ameijeiras S, Cabanes DJE, Hassler CS (2019) Towards the development of a new generation of whole-cell bioreporters to sense iron bioavailability in oceanic systems-learning from the case of Synechococcus sp. PCC7002 iron bioreporter. J Appl Microbiol 127:1291-1304. https://doi.org/10.1111/jam.14277

8. Bradford MM (1976) A rapid and sensitive method for the quantitation of microgram quantities of protein utilizing the principle of protein-dye binding. Anal Biochem 72:248-254. https://doi. org/10.1006/abio.1976.9999

9. Collin F (2019) Chemical basis of reactive oxygen species reactivity and involvement in neurodegenerative diseases. Int J Mol Sci. https://doi.org/10.3390/ijms20102407

10. Daspute AA, Sadhukhan A, Tokizawa M, Kobayashi Y, Panda SK, Koyama $\mathrm{H}$ (2017) Transcriptional regulation of aluminum-tolerance genes in higher plants: clarifying the underlying molecular mechanisms. Front Plant Sci 8:1358. https://doi.org/10.3389/ fpls.2017.01358

11. De Schamphelaere KA, Vasconcelos FM, Heijerick DG, Tack FM, Delbeke K, Allen HE, Janssen CR (2003) Development and field validation of a predictive copper toxicity model for the green alga Pseudokirchneriella subcapitata. Environ Toxicol Chem 22:2454-2465. https://doi.org/10.1897/02-499

12. Elbaz A, Wei YY, Meng Q, Zheng Q, Yang ZM (2010) Mercuryinduced oxidative stress and impact on antioxidant enzymes in Chlamydomonas reinhardtii. Ecotoxicology (London, England) 19:1285-1293. https://doi.org/10.1007/s10646-010-0514-z

13. Emamverdian A, Ding Y, Mokhberdoran F, Xie Y (2015) Heavy metal stress and some mechanisms of plant defense response. Sci World J 2015:756120. https://doi.org/10.1155/2015/756120

14. Fatma $T$ (2009) Screening of cyanobacteria for phycobiliproteins and effect of different environmental stress on its yield. Bull Environ Contam Toxicol 83:509-515. https://doi.org/10.1007/ s00128-009-9837-y

15. Franklin NM, Stauber JL, Markich SJ, Lim RP (2000) pH-dependent toxicity of copper and uranium to a tropical freshwater alga (Chlorella sp.). Aquat Toxicol (Amst Neth) 48:275-289

16. Gaetke LM, Chow-Johnson HS, Chow CK (2014) Copper: toxicological relevance and mechanisms. Arch Toxicol 88:1929-1938. https://doi.org/10.1007/s00204-014-1355-y

17. Hiruma K (2019) Roles of plant-derived secondary metabolites during interactions with pathogenic and beneficial microbes under conditions of environmental stress. Microorganisms. https://doi.org/10.3390/microorganisms7090362

18. Horváth H, Kovács AW, Riddick C, Présing M (2013) Extraction methods for phycocyanin determination in freshwater filamentous cyanobacteria and their application in a shallow lake. Eur J Phycol 48:278-286. https://doi.org/10.1080/09670 262.2013.821525

19. Khan MN, Mobin M, Abbas ZK, AIMutairi KA, Siddiqui ZH (2017) Role of nanomaterials in plants under challenging environments. Plant Physiol Biochem PPB 110:194-209. https://doi. org/10.1016/j.plaphy.2016.05.038

20. Khanna-Chopra R, Jajoo A, Semwal VK (2011) Chloroplasts and mitochondria have multiple heat tolerant isozymes of SOD and APX in leaf and inflorescence in Chenopodium album. Biochem Biophys Res Commun 412:522-525. https://doi.org/10.1016/j. bbrc.2011.06.179
21. Kosova K, Vitamvas P, Urban MO, Prasil IT, Renaut J (2018) Plant abiotic stress proteomics: the major factors determining alterations in cellular proteome. Front Plant Sci 9:122. https://doi. org/10.3389/fpls.2018.00122

22. Kovacik J, Dresler S (2018) Calcium availability but not its content modulates metal toxicity in Scenedesmus quadricauda. Ecotoxicol Environ Saf 147:664-669. https://doi.org/10.1016/j.ecoen v.2017.09.022

23. Kukarskikh GL, Graevskaia EE, Krendeleva TE, Timofeedv KN, Rubin AB (2003) Effect of methylmercury on primary photosynthesis processes in green microalgae Chlamydomonas reinhardtii. Biofizika 48:853-859

24. Li D, Li C, Sun H, Wang W, Liu L, Zhang Y (2010) Effects of drought on soluble protein content and protective enzyme system in cotton leaves. Front Agric China 4:56-62. https://doi. org/10.1007/s11703-010-0102-2

25. Lustigman B, Lee LH, Weiss-Magasic C (1995) Effects of cobalt and $\mathrm{pH}$ on the growth of Chlamydomonas reinhardtii. Bull Environ Contam Toxicol 55:65-72. https://doi.org/10.1007/bf002 12390

26. Mahmud JA, Hasanuzzaman M, Khan MIR, Nahar K, Fujita M (2020) beta-Aminobutyric acid pretreatment confers salt stress tolerance in Brassica napus $\mathrm{L}$ by modulating reactive oxygen species metabolism and methylglyoxal detoxification. Plants (Basel, Switzerland). https://doi.org/10.3390/plants9020241

27. Minhas AK, Hodgson P, Barrow CJ, Adholeya A (2016) A review on the assessment of stress conditions for simultaneous production of Microalgal Lipids and Carotenoids. Front Microbiol 7:546. https://doi.org/10.3389/fmicb.2016.00546

28. Mohan Murali Achary V, Patnaik AR, Panda BB (2012) Oxidative biomarkers in leaf tissue of barley seedlings in response to aluminum stress. Ecotoxicol Environ Saf 75:16-26. https://doi. org/10.1016/j.ecoenv.2011.08.015

29. Murali Achary VM, Panda BB (2010) Aluminium-induced DNA damage and adaptive response to genotoxic stress in plant cells are mediated through reactive oxygen intermediates. Mutagenesis 25:201-209. https://doi.org/10.1093/mutage/gep063

30. Panda BB, Achary VM (2014) Mitogen-activated protein kinase signal transduction and DNA repair network are involved in aluminum-induced DNA damage and adaptive response in root cells of Allium cepa L. Front Plant Sci 5:256. https://doi. org/10.3389/fpls.2014.00256

31. Priyadarshini E, Priyadarshini SS, Pradhan N (2019) Heavy metal resistance in algae and its application for metal nanoparticle synthesis. Appl Microbiol Biotechnol 103:3297-3316. https:// doi.org/10.1007/s00253-019-09685-3

32. Puente-Sanchez F, Diaz S, Penacho V, Aguilera A, Olsson S (2018) Basis of genetic adaptation to heavy metal stress in the acidophilic green alga Chlamydomonas acidophila. Aquat Toxicol (Amst Neth) 200:62-72. https://doi.org/10.1016/j.aquat ox.2018.04.020

33. Rodriguez-Serrano $M$, Romero-Puertas MC, Pazmino DM, Testillano PS, Risueno MC, Del Rio LA, Sandalio LM (2009) Cellular response of pea plants to cadmium toxicity: cross talk between reactive oxygen species, nitric oxide, and calcium. Plant Physiol 150:229-243. https://doi.org/10.1104/pp.108.131524

34. Saleem MH et al (2020) Jute: a potential candidate for phytoremediation of metals - a review. Plants (Basel, Switzerland). https ://doi.org/10.3390/plants9020258

35. Schutzendubel A, Polle A (2002) Plant responses to abiotic stresses: heavy metal-induced oxidative stress and protection by mycorrhization. J Exp Bot 53:1351-1365

36. Ullrich WR (1971) The influence of $\mathrm{CO}_{2}$ and $\mathrm{pH}$ on (32)P-labelling of polyphosphates and organic phosphates in Ankistrodesmus braunii in the light. Planta 102:37-54. https://doi.org/10.1007/ bf00391448 
37. Wellburn AR (1994) The spectral determination of chlorophylls $a$ and $b$, as well as total carotenoids, using various solvents with spectrophotometers of different resolution. J Plant Physiol 144:307-313

38. Zhang X, Sun N, Wu L, Xu M, Bingham IJ, Li Z (2016) Effects of enhancing soil organic carbon sequestration in the topsoil by fertilization on crop productivity and stability: evidence from long-term experiments with wheat-maize cropping systems in
China. Sci Total Environ 562:247-259. https://doi.org/10.1016/j. scitotenv.2016.03.193

Publisher's Note Springer Nature remains neutral with regard to jurisdictional claims in published maps and institutional affiliations. 